\title{
透析患者における胃排出能の検討
}

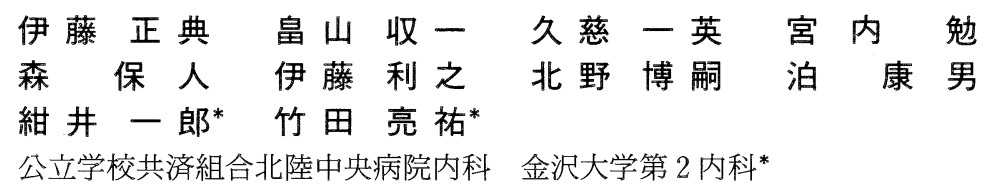

key words：血液透析, 胃排出能, 自律神経障害, 糖尿病性腎症

〈要旨〉

維持血液透析患者を対象として, アイソトープ法による胃排出能 (GE) を測定し, 胃運動機能を評価し, さらに自 律神経機能および消化管ホルモンとの関連を検討したので報告する.

当院における維持血液透析患者 25 例を対象として, 糖尿病性腎症に由来する DM 群 8 例（男 5 例, 女 3 例, 平均 年齢 51.4 歳), 非 DM 群 17 例（男 9 例, 女 8 例）の 2 群に分け以下の検討を行った. GE の検討では, 固形食として オムレツ食, 液体食として市販流動食に, それぞれ ${ }^{99 \mathrm{~m} T} \mathrm{Tc}$ スズコロイドを混合したものを用いた。固形食は, 摂食後 60 分の胃内 RI 残存率 (GR), 液体食は, 胃内 RI 半減時間 ( $\left.T^{1} / 2\right)$ を GE の指標とした。 なお, 健常人 6 例を対照群と して同様の検討を行った，自律神経機能の評価は，心電図 R-R 間隔変動係数 $\left(C V_{R-R}\right)$ を計測して，正常健常人 145 例より求めた各年代別の平均值から, 一 1SD 以下を自律神経障害 $(A D)$ 群とした。また, 消化管ホルモンとして, 血 清ガストリンおよび血漿モチリンを測定し, GE との関連を検討した。

固形食 GR は, DM 群で平均 $72.0 \pm 11.3 \%$, 非 DM 群 $59.2 \pm 14.3 \%$, 健常者群 $50.1 \pm 9.9 \%$ 2 群に比べ有意 に高值をとった。一方, 液体食 $T \frac{1}{2} /$ は DM 群で平均 162.3 分, 非 DM 群で 103.1 分といずれも, 健常者群平均 49.5 分と比較して有意に高值を示した。 なお, $G R$ と T $1 \frac{1}{2}$ の間には有意な負の相関関係が見られた. $\mathrm{CV}_{\mathrm{R}-\mathrm{R}}$ の結果から, $\mathrm{DM}$ 群では全例が $\mathrm{AD}$ 群に属し, GE 遅延と $\mathrm{AD}$ との関連が示唆された. 非 DM 群でも $43.8 \%$ が $\mathrm{AD}$ 群に属したが, GE との有意な関連は認められなかった，また，ガストリンおよびモチリンの血中レベルと GE との間に有意な相関 関係は見られなかった。

以上, DM 群では固形食, 液体食ともに, GE遅延が認められ, その成因に自律神経障害の関与が示唆された。一方, 非 DM 群でも液体食 GE は遅延しており, 胃運動機能は障害されている可能性が示唆されたが, 自律神経障害以外の 要因を検討する必要があると思われた。

\section{Assessment of gastric emptying in hemodialysis patients}

Masanori Itoh, Shuichi Hatakeyama, Kazuhide Kuji, Tsutomu Miyauchi, Yasuhito Mori, Toshiyuki Itoh, Hiroshi Kitano, Yasuo Tomari, Ichirou Koni*, Ryoyu Takeda*

Department of Internal Medicine, Hokuriku Central Hospital of the Mutual Aid Association of Public School Teachers ; Second Department of Internal Medicine, Kanazawa University*

In order to evaluate gastric motility in patients undergoing hemodialysis (HD), we measured gastric emptying (GE) in $25 \mathrm{HD}$ patients (8 diabetics, 17 non-diabetics) by the radioisotope method. Autonomic nerve function and gut hormone levels were also examined.

${ }^{99 m} \mathrm{Tc}$-labeled solid and liquid meals were used for the estimation of GE. Percentage of gastric retention (GR) of $R I$ at 60 min after ingestion of a solid meal, and the half time $\left(T^{1} / 2\right)$ of a labeled liquid meal were used as indicators marker of GE. GE was also measured in 6 normal controls. Autonomic nerve function was evaluated by the RR interval on an electrocardiogram $\left(\mathrm{CV}_{\mathrm{R}-\mathrm{R}}\right)$, and gut hormone, gastrin and motilin levels were measured

伊藤 正典 現 金沢大学第 2 内科 T920 金沢市宝町 13-1 (0762-62-8151)

〔受付: 平成 3 年 12 月 9 日，受理：平成 4 年 7 月 8 日) 
before starting hemodialysis.

A significant positive relationship was observed between the value of GR of a solid meal and the $T 1 / 2$ of a liquid meal. The values of GR of a solid meal in HD diabetics $(72.0 \pm 11.3 \%)$ were significantly higher than those in HD

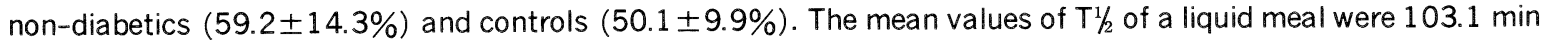
in HD non-diabetics, and $162.3 \mathrm{~min}$ in HD diabetics, which were significantly higher than the values in controls (mean $49.5 \mathrm{~min}$ ). There was no significant relationship between GE and gut hormone level in either group. Although there was no relationship between $G E$ and $C V_{R-R}$ in $H D$ non-diabetics, autonomic nerve dysfunction as evaluated by $\mathrm{CV}_{\mathrm{R}-\mathrm{R}}$ was observed in all $\mathrm{HD}$ diabetics.

It is suggested that in HD diabetics autonomic nerve dysfunction might result in disturbed GE of both solid and liquid meals. In HD non-diabetics, the pathogenesis of disturbed GE should be further investigated.

\section{はじめに}

慢性腎不全患者, 殊に透析患者においては, 食欲不振, 悪心, 便秘などの消化器症状が高頻度にみられ, それが 低栄養状態につながっている.消化管運動は自律神経に より支配されているが, 透析患者においては, 自律神経 障害の存在を示唆する所見が多くみられて抢り ${ }^{1 \sim 3)}$, 今 回, アイソトープ法による胃排出能検査を行って, 胃運 動機能を検討したので報告する。

\section{対象と方法}

当院に抢ける維持血液透析患者男 14 例，女 11 例，計 25 例を対象とした。これを糖尿病群 8 例(DM 群：男 5 , 女 3 ） と, 非糖尿病群 17 例（非 DM 群：男 9 , 女 8 ) の 2 群に分け, 以下の検討を行った。DM 群，非 DM 群 各々の平均年齢は 65.8 歳扝よび 51.4 歳であり, 平均透 析期間は，30.0 か月抢よび 90.8 か月であった。 DM 群 は, 非 DM 群に比べ有意に年齢は高值であり, 透析期間 は有意に短く, 全例 Scott II 以上の網膜症を有していた。 8 例中 5 例がインスリン療法中であり, また 1 例が経口 血糖降下剂を内服していた。

1. 固形食胃排出能の検討

患者は，通常の朝食を摂った後に絶食とし，検査終了 まで昼食は待機させ, 正午から午後 1 時の時間帯で検査 を行った。鷄卵 2 個中に ${ }^{99 \mathrm{~m}} \mathrm{Tc}$ スズコロイド $185 \mathrm{MBq}$ を混合して調理したオムレッと，トースト 1 枚計約 250 $\mathrm{kcal}$ を摂取させ，摂食後，患者腹側にガンマカメラを設 置して, 臥位の姿勢で連続的に胃内の RI カウントを測 定した。な㧍，摄食中の飲水は特に制限せず，また摄食 時間も特に制限しなかった。計測時間は最低 90 分間実施 したが，既知のごとく，固形食の胃排出には $1 \mathrm{ag}$ time が 存在するため, 胃排出能の指標として, 摂食後 60 分後の 胃内 RI 残存率 $(G R)$ を用いた。

\section{2 . 液体食胃排出能の検討}

液体食は，固形食と同じ条件で三和化学社製サンエッ ト-A (Sanet-A ${ }^{\circledR}$ ) $200 \mathrm{~m} l$ 中に, 固形食と同じく, ${ }^{99 \mathrm{~m}} \mathrm{Tc}-$ スズコロイド $185 \mathrm{MBq}$ を混合して，患者に飲食させ，
固形食と同じく臥位にて胃内 RI カウントを連続的に測 定した。排出能の指標は胃内 RI の半減時間 $\left(T^{1} / 2\right)$ を用 いた。なお，固形食，液体食とも，明らかな胃腸疾患の ない健常人 6 例を対照として同様の検討を行った.

3 。穴電図 $R-R$ 間隔変動係数 $\left(C V_{R-R}\right.$ 值 $)$ の検討

簡便かつ非侵襲的，定量的に自律神経機能を評価する 目的で, 心電図 $\mathrm{CV}_{\mathrm{R}-\mathrm{R}}$ を検討した。透析開始前に，約 10 分間の安静後に心電図を記録し, フクダ電子社製 FCP3000 により, $\mathrm{CV}_{\mathrm{R}-\mathrm{R}}$ を求めた。 1 か月毎に計 3 回測定し, 平均值をとった： $\mathrm{CV}_{\mathrm{R}-\mathrm{R}}$ は，加齢とともに低下すること が報告されておりり ち, 明らかな不整脈, 糖尿病歴のなかった 145 名を対象 として $\mathrm{CV}_{\mathrm{R}-\mathrm{R}}$ を計測し, 各年代別に平均値および標準偏 差 (SD) を求めた。これを対照として, - $1 \mathrm{SD}$ 以下を自 律神経障害 $(\mathrm{AD})$ 群とした。

4.ガストリン，モチリン測定

ガストリンおよびモチリンは生理作用として，胃運動 を促進する，透析患者では，血清ガストリンの高值をと る症例が存在し，その成因に腎での排泄低下が考えられ ている ${ }^{4)}$.このことから今回, 透析前に採血を行い, 血清 ガストリン值, および血漿モチリン值を RIA 法にて測定 し，胃排出能との関連を検討した。な扔数值は，平 均值士標準偏差 $($ mean $\pm \mathrm{SD})$ で表示し, 群間の比較は Student's t-test を用い, $\mathrm{p}<0.05$ をもって有意とした。

結果

1. 固形食胃排出能

今回検討した試験食摂取後 60 分の胃内残存率 $(\mathrm{GR})$ の結果を図 1 に示す. DM 群で平均 $72.0 \pm 11.3 \%$ であっ たのに対し, 非 DM 群 $59.2 \pm 14.3 \%$, 対照群 $50.1 \pm$ $9.9 \%$ となり, DM 群では他 2 群に比較して有意に高值を 示した。なお非 DM 群においては，対照群と有意差はな かったものの高值をとる傾向が認められた。

2 . 液体食胃排出能

図 2 に結果を示す。液体食摄取後の半減時間 $\mathrm{T}^{1} / 2$ は, $\mathrm{DM}$ 群, 非 DM 群ともかなりばらつきが多いものの, 


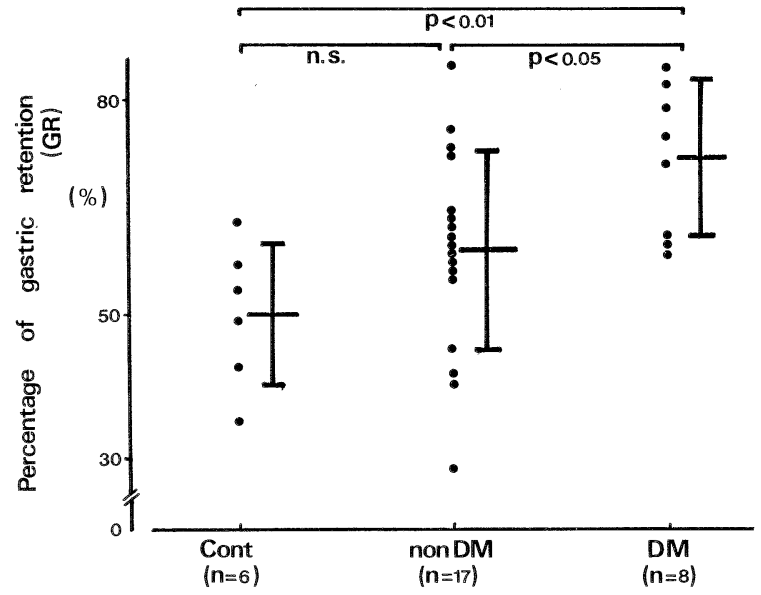

図 1 Gastric retention rate of the solid meal

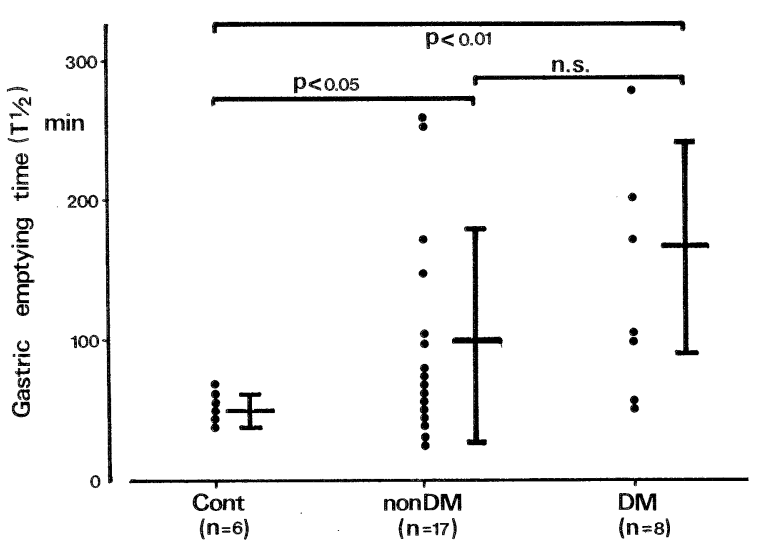

図 2 Gastric emptying half time of the liquid meal

DM 群で平均 $162.3 \pm 74.8$ 分, 非 DM 群で $103.1 \pm 78.2$ 分といずれも正常対照 $49.5 \pm 12.6$ 分と比べ有意に高值 を示した。しかし, 非 DM 群と DM 群の間に有意差は 認められなかった。

固形食 GR と, 液体食 $T^{1} / 2$ との間には図 3 に示すご とく, $\mathrm{r}=0.548$ と正の相関関係がみられ, 胃排出遅延患 者では, 固形食, 液体食ともに障害されている可能性が 考えられた。

3. $\mathrm{CV}_{\mathrm{R}-\mathrm{R}}$ と胃排出能との関連について

図 4 に固形食および液体食胃排出能と $\mathrm{CV}_{\mathrm{R}-\mathrm{R}}$ との関 係について示した。図 4 左に示すように, 固形食 GR と $\mathrm{CV}_{\mathrm{R}-\mathrm{R}}$ との間には， $\mathrm{r}=-0.525$ と有意な負の相関関係 が見られ， $\mathrm{CV}_{\mathrm{R}-\mathrm{R}}$ の低下している患者ほど GR は高值を とることが示された。しかし，図 4 右に示すように， $C V_{\mathrm{R}-\mathrm{R}}$ は液体食半減時間との間には有意な相関関係は 見られなかった。 なお, 非 $\mathrm{DM}$ 群の 1 例で $\mathrm{CV}_{\mathrm{R}-\mathrm{R}}$ が

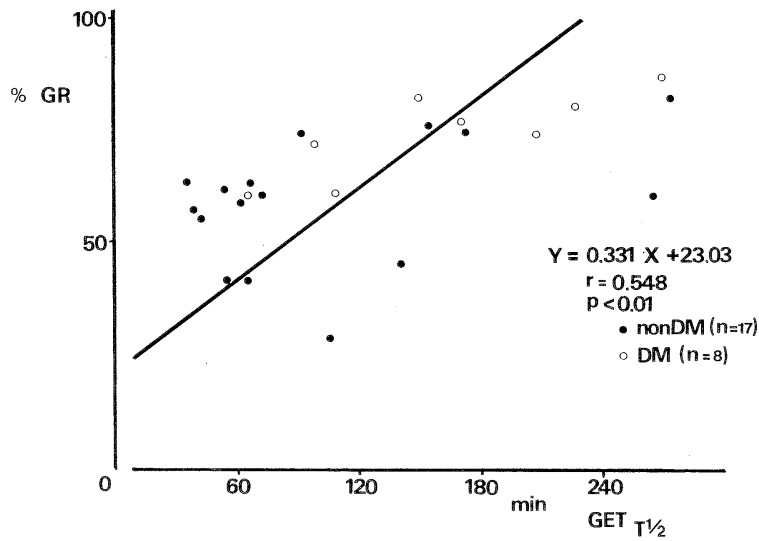

図 3 Relationship between emptying of solid meal (GR) and liquid meal $\left(\mathrm{T}^{1} / 2\right)$
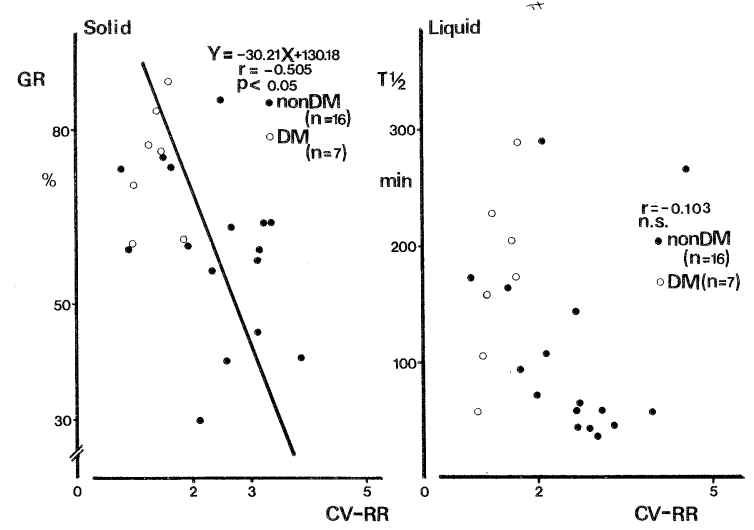

図 4 Relationship between $\mathrm{CV}_{\mathrm{R}-\mathrm{R}}$ and gastric emptying

表 The mean value of $\mathrm{CV}_{\mathrm{R}-\mathrm{R}}$ in controls

\begin{tabular}{c|c|c|c}
\hline Age & $\mathrm{N}$ & Male & Female \\
\hline$\sim 30$ & 15 & $4.17 \pm 0.49$ & $5.52 \pm 1.27$ \\
\hline $31 \sim 40$ & 28 & $4.56 \pm 1.22$ & $4.44 \pm 1.27$ \\
\hline $41 \sim 50$ & 38 & $4.26 \pm 1.13$ & $4.32 \pm 1.21$ \\
\hline $51 \sim 60$ & 38 & $3.76 \pm 1.23$ & $3.84 \pm 0.99$ \\
\hline $61 \sim$ & 26 & $2.56 \pm 0.93$ & $2.71 \pm 1.11$ \\
\hline
\end{tabular}

4.59\%と高值をとっていたが，棄却検定では有意に棄却 されなかった点を附記する。次に, 正常対照群より求め た各年代別の $\mathrm{CV}_{\mathrm{R}-\mathrm{R}}$ の平均值を表に示した。従来の報告 どおり，加齢とともに $\mathrm{CV}_{\mathrm{R}-\mathrm{R}}$ は低下する傾向を示した。 これをもとに, - $1 \mathrm{SD}$ 以下を自律神経障害群 ( $\mathrm{AD}$ 群) と すると， $\mathrm{DM}$ 群では 8 例全例が $\mathrm{AD}$ 群に属した.このこ とから, $\mathrm{AD}$ の存在が, DM 群における胃排出遅延に関 与している可能性が示唆された。一方, 非 DM 群では 17 

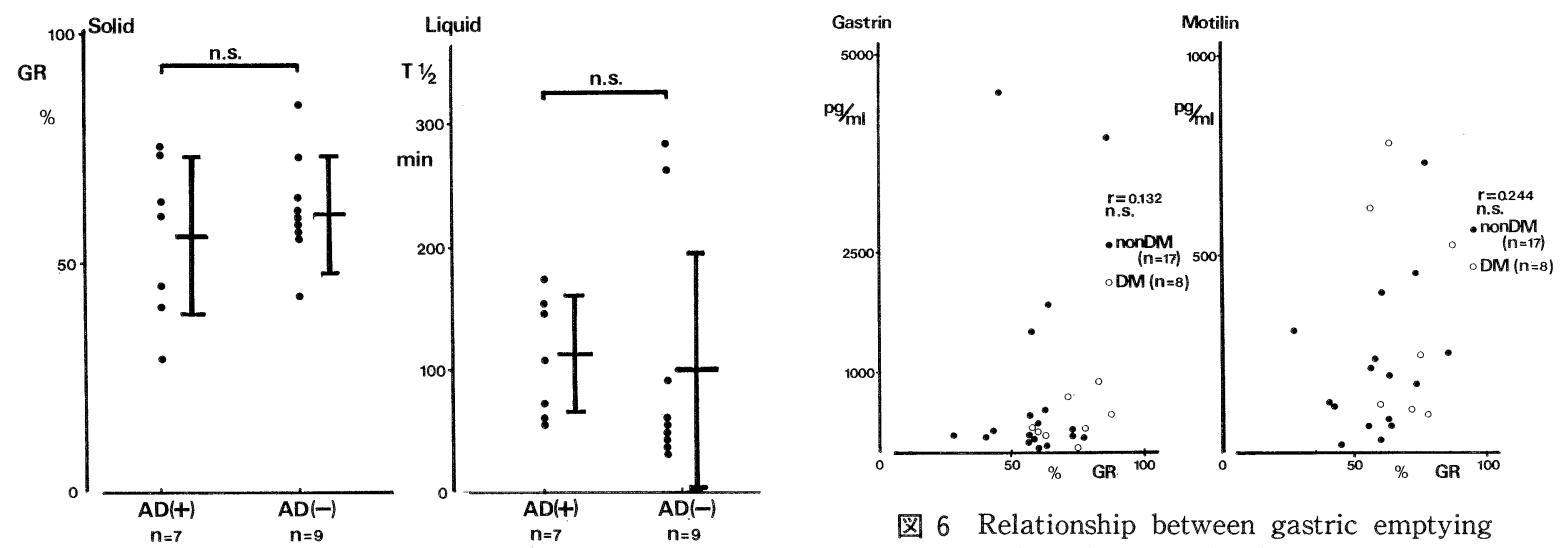

図 6 Relationship between gastric emptying and gut hormone levels in HD patients

図 5 Gastric emptying in $\mathrm{AD}(+)$ group and $\mathrm{AD}(-)$ group in non-diabetics

例中 7 例 (43.8\%) が $\mathrm{AD}(+)$ となった。このことか ら非 DM 群においても $\mathrm{AD}$ の有無が, 胃排出能に影響 を及漹しているかどうかについて検討した。しかし図 5 に示すごとく, 非 DM 群においては, 固形食 GR, 液体 食 $\mathrm{T}^{1 / 2}$ ともに, $\mathrm{AD}(+)$ 群と $\mathrm{AD}(-)$ 群の間に有意な 差はなく, 図 2 で示された非 DM 群における有意な液体 食排出遅延については, 自律神経障害以外の因子も考元 る必要があると考えられた。

4. 消化管ホルモンと胃排出能との関連について

透析前採血により求めた血清ガストリン值の平均は, 非 DM 群で $869.8 \pm 1,362.6 \mathrm{pg} / \mathrm{m} l$, DM 群で $352.8 \pm$ $278.9 \mathrm{pg} / \mathrm{m} l$ となり, 両群に有意差はなかった。一方, 血 漿モチリン值についても, 非 DM 群で $227.2 \pm 176.9 \mathrm{pg} /$ $\mathrm{m} l, \mathrm{DM}$ 群で $354.5 \pm 282.8 \mathrm{pg} / \mathrm{m} l$ とこちらも有意差は なかった. 図 6 にガストリンおよびモチリン值を固形食 GR との相関関係を示したが，ともに有意な相関関係は 得られなかった。液体食 $\mathrm{T}^{1} / 2$ との間にも同様に有意な相 関関係は得られなかった。

\section{考察}

慢性腎不全患者, とくに血液透析患者に扔いては，食 欲不振, 嘔気, 便秘などの消化器症状が高頻度に見られ る。殊に糖尿病性腎症由来の透析患者に抢いては, その 症状が高度で, 治療に難渋するばかりか, 栄養不良状態 が進行し, 生命予後に影響を及ぼす可能性もある。近年, 器質性病変を認めないにもかかわらず, 上腹部不定愁訴 を訴える病態について, Non ulcer dyspepsia という概 念が提唱され 運動異常が指摘されている, 透析患者においては, 尿毒 症性神経症の 1 つの分症として自律神経障害が存在する ことについて報告が多いが ${ }^{1 \sim 3)}$, 胃運動機能を検討した報 告は少ない, ${ }^{6,7)}$ ここのこ功, 今回, 我々はアイソトー

プ法による胃排出能 (GE) を検討した。現在, 胃運動機 能の評価法として，GE 測定が最も頻繁に使用されてお り, 糖尿病をはじめ各種疾患での報告 ${ }^{8 \sim 14)}$ が見られる. $\mathrm{GE}$ 測定法については, アイソトープ法および,アセトア ミノフェン法が代表であるが, 後者の方法は, アセトア ミノフェンが肝でグルクロン酸抱合をうけ，腎へ排泄さ れるため, 腎機能の廃絶した透析患者においては血中レ ベルが高值をとる可能性がある。また,アセトアミノフェ ンの副作用を防ぐため, 検査は透析前に実施する方が安 全であると，宾戸ら ${ }^{6)}$ は報告している。一方，アイソトー プ法は，再現性も高く，透析患者に実施しても，大きな 侵襲にはならない点ですぐれていることから，アイソ トープ法により GE を評価した。

さて, 今回の結果では, DM 群では, 固形食, 流動食 ともに健常人と比較して, GE 遅延が認められた。自律神 経機能の検査法である心電図 $\mathrm{CV}_{\mathrm{R}-\mathrm{R}}$ の検討においても, $\mathrm{DM}$ 群では全例がー1SD 以下の值をとり, 自律神経障害 (AD) が存在すると考えられたことから，DM群では $\mathrm{AD}$ と $\mathrm{GE}$ 遅延との関連が示唆された。糖尿病患者にお いて, $\mathrm{GE}$ 遅延を認めた報告は多く ${ }^{8 \sim 13)}$, その成因に $\mathrm{AD}$ の関与も示唆したものも多い. Loo ら ${ }^{8)}$ は, 糖尿病患者の $\mathrm{GE}$ は, 神経障害が高度になれば, 固形食, 液体食ともに 障害されると報告していることから，今回検討した DM 群においては, 高度の自律神経障害が存在すると推定さ れる.アセトアミノフェン法を用いて, 透析患者の $\mathrm{GE}$ を 検討した宍戸ら ${ }^{6)}$ も， DM 透析患者での $\mathrm{GE}$ 遅延を報告 している。なお，DM 群は高齢患者が多かったため, 加

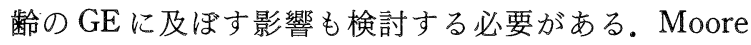
$ら^{15)}$ の検討では, 老年者の液体食の胃排出能は若年者と 比較して, 有意に遅延していたが, 固形食排出には有意 差はみられでおらず，今回の DM 群の GE の結果は加 齢のみでは説明できないと考えられる。 
一方, 非 DM 群については, 液体食では健常人と比較 して，有意な排出遅延が認められた。しかし， $\mathrm{CV}_{\mathrm{R}-\mathrm{R}}$ に 基づく $\mathrm{AD}$ の有無では特に有意差を見出せなかった，従 来の報告では，非 DM 群については，GE 遅延の有無に

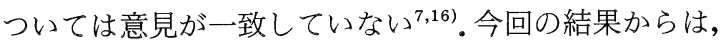
自律神経障害以外の因子の関与も $\mathrm{GE}$ 遅延の機序として 考える必要があると思われた。その 1 つとして, 消化管 ホルモンの GEに及ぼす影響を検討した。糖尿病患者を 対象とした検討では, 中目ら ${ }^{17}$ はモチリンとの関連を,ま た，鈴木ら ${ }^{12)}$ はガストリンと $\mathrm{GE}$ との関連を示唆してい るが，今回は有意な関連は認められなかった。ただし， 今回の採血は透析前の採血であり, 試験食摂取中のデー 夕ではないため, この点についてはさらに検討が必要で ある。また, Siamopoulos ら ${ }^{18)}$ は透析患者の食道運動機 能の低下を報告しているが，その成因の 1 つに平滑笳障 害の存在を示唆しており，尿毒症性筋症も $\mathrm{GE}$ 遅延に関 係している可能性も考えられる。

なお，消化管運動異常に対する薬物治療として, metoclopramide や domperidone などに加え, コリン作働性 ニューロンからのアセチルコリン放出を促進する cisapride も高い有効性が指摘され, 透析患者に使用した報 告も見られる ${ }^{19)}$. 今後, 薬剤投与での GE の変化も検討 する必要があると思われる。

\section{まとめ}

1. DM 群では, 固形食, 液体食ともに胃排出遅延が 認められた. $\mathrm{CV}_{\mathrm{R}-\mathrm{R}}$ の結果からは, 全例が自律神経障害 を持つことが示唆され, 胃排出遅延も自律神経障害の反 映と思われた。

2. 非 DM 群では，液体食で有意な排出遅延がみられ たが, $\mathrm{CV}_{\mathrm{R}-\mathrm{R}}$ の低下の有無との間には有意な関係は見ら れなかった。

3. 今回の検討では, 透析患者の血中ガストリンおよ びモチリン值と, 胃排出能との間には, 有意な関連は見 られなかった。

本文の要旨は, 第 36 回日本透析療法学会総会(神戸, 1991) に扔いて発表した。

\section{文献}

1) Bondia A, Tabernero JM, Macias JF, Martin -Luengo $\mathrm{C}$ : Autonomic nervous system in haemodialysis. Nephrol Dial Transplant 2:174 $-180,1988$

2) 石原 哲, 前田真一, 小林 寛, 清 正夫, 羽鳥浩 司, 鈴木広明, 北島和一, 看日善男, 小林克寿, 斉 藤昭弘, 西浦常雄: 慢性腎不全患者の自律神経障害
一心電図 R-R 間隔を指標として一. 透析会誌 19 ： 905-909, 1986

3）大野 敦，金澤 昭，植木涁夫，伊藤久雄：慢性血 液透析患者の自律神経障害一心電図 $\mathrm{R}-\mathrm{R}$ 間隔変動 係数と自律神経自覚症状スコアーを用いた検討一. 自律神経 $26: 440-445 ， 1989$

4）武藤重明, 浅野 泰, 宮田正夫：慢性腎不全とガス トリン。腎と透析 $19: 595-601,1985$

5）原澤 茂：胃の運動異常. 臨床消化器内科 4 : 223234, 1989

6）宾戸 洋, 藤倉良裕, 我妻慎一, 関野 宏, 二木 源, 門間弘道, 高橋 寿, 安海 清, 浅木 茂, 後藤由 夫 : 慢性透析患者の胃排出能, 小腸透過時間の検討. 透析会誌 $19: 819-825,1986$

7) Wright $A R$, Clemente $R$, Wathen $R$ : Gastric emptying in patients with chronic renal failure receiving hemodialysis. Arch Intern Med 144 : 495 $-496,1984$

8) Loo FD, Palmer DW, Soergel KH, Kalbfleisch JH, Wood $\mathrm{CH}$ : Gastric emptying in patients with diabetes mellitus. Gastroenterology $86: 485-494$, 1984

9) Varis K : Diabetic Gastroparesis. Scand J Gastroenterol $24: 897-903,1989$

10) Horowitz M, Harding PE, Maddox AF, Wishart JM, Akkermans LMA, Chatterton BE, Shearman DJC: Gastric and esophageal emptying in patients with type 2 (non-insulin-dependent) diabetes mellitus. Diabetologia 32 : 151-159, 1989

11）林 善峰, 本郷道夫, 佐竹賢三, 豊田隆謙, 後藤由 夫, 奥山信一：糖尿病患者に扔ける胃排出能の検討. 日消誌 $84 ： 1-5,1987$

12）鈴木吉彦，松岡健平：糖尿病胃症に及涩す糖尿病性 神経障害と血糖コントロールの影響. 糖尿病 33 ： $635-640,1990$

13）荒木一郎：糖尿病に伴う胃排出障害の病因に関する 研究。十全医学会雑誌 $97: 204-217,1988$

14) Domstad PA, Shin W, Humphries L, Deland FH, Digenis GA: Radionuclide gastric emptying studies in patients with anorexia nervosa. J Nucl Med $28: 816-819,1987$

15) Moore JG, Tweedy C, Christian PE, Datz FL: Effect of age on gastric emptying of liquid-solid meals in man. Dig Dis Sci 28 : 340-344, 1983

16) Sevy N, Snape JW : Gastrointestinal abnormelities In "Textbook of Nephrology" ed Massry 
SG, Glassock RJ, p1211 1212, Williams \& Wilkius Baltimore, 1989

17）中目千之, 赤井裕輝, 本郷道夫, 今井信行, 豊田隆 謙, 後藤由夫, 奥口文宜, 小松宽治：糖尿病患者に おける消化管運動障害と高モチリン血症. 日消誌 79 : 2207-2215, 1982

18) Siamopoulos KC, Tsianos EV, Dardamonis M,
Berecos C: Esophageal dysfunction in chronic hemodialysis patients. Nephron 55 : 389-393, 1990

19) Lazarovits IA, Page $D$ : Intraperitoneal cisapride for the treatment of diabetes with gastroparesis and end-stage renal disease. Nephron 56:107 $-109,1990$ 